\title{
Tagetes patula L. Bitkisinin Fitoremediasyon Amaçlı Kullanım Potansiyelinin Su Kültürü Koșullarında Araștırılması
}

\author{
Hatice DAĞHAN*
}

Eskișehir Osmangazi Üniversitesi, Ziraat Fakültesi, Toprak Bilimi ve Bitki Besleme Bölümü, Eskișehir

\author{
*Sorumlu yazar e-posta (Corresponding author e-mail) : hdaghan@ogu.edu.tr \\ Geliș tarihi (Received) : 12.05.2016 \\ Kabul tarihi (Accepted): 09.09.2016
}

\section{Öz}

Çeșitli kaynaklardan toprağa katılan kadmiyum (Cd) bitki büyüme ve gelișmesini azaltan ve besin zincirine katıldığında canlılar için tehlikeli olan toksik bir metaldir. Özellikle ucuz, etkili, çevre dostu ve uygulanması kolay fitoremediasyon yöntemi kullanılarak $\mathrm{Cd}$ ile kirlenmiș tarım topraklarının temizlenmesi için hiperakümülatör bitkilerin araștıııması gerekmektedir. Bu amaçla Tagetes patula L. (Kadife çiçeği) bitkisinin Cd hiperakümülasyon potansiyeli araștırımıștır. Deneme artan dozlarda (0-5-10-20-40 $\mu \mathrm{M})$ ve $8 \mathrm{CdSO}_{4} .7 \mathrm{H}_{2} \mathrm{O}$ formunda uygulanmıș Cd'un su kültürü ortamında Tagetes patula L. bitkisinin Cd akümülasyonu, bakır (Cu), demir (Fe), çinko (Zn), mangan (Mn) ve indirgenmiș glutatyon konsantrasyonuna etkileri araștırıımıștır. Bitkiler 15 gün süre ile üç paralelli olarak Hoagland besin solüsyonunda kontrollü koșullarda yetiștirilmiștir. Deneme sonunda Cd uygulamalarındaki artıșla bitkilerin yeșil aksam ve kök kuru ağırlıklarındaki azalmaya rağmen Cd konsantrasyonlarında ve içeriklerinde (kontentlerinde) bir artıș olmuștur. Tagetes patula L. bitkisi yeșil aksamında hiperakümülasyon değerinin (100 mg Cd kg-1) 8 katı Cd biriktirmiștir. Bu sonuç Tagetes patula L. bitkisinin Cd ile kirlenmiș toprakların fitoremediasyonunda kullanım potansiyelinin yüksek olduğunu göstermiștir.

Anahtar Kelimeler: Ağır metal, fitoremediasyon, indirgenmiș glutatyon, kadmiyum, Tagetes patula L.

\section{Investigation of Phytoremediation Potential of Tagetes patula L. Plant in Hydroponic Culture Conditions}

\begin{abstract}
Cadmium entering soil from various sources is a very serious problem for plant and animal growth and development when it participates in food chain. Particularly hyperaccumulator plants should be investigated for phytoremediation of cadmium contaminated agricultural lands so that it is a cheap, efficient and environmentally friendly method. For this purpose, Cd hyperaccumulation potential of Tagetes patula L. plant was investigated. The effects of increasing Cd doses (0-5-10-20-40 MM) in $8 \mathrm{CdSO}_{4} \cdot 7 \mathrm{H}_{2} \mathrm{O}$ form on $\mathrm{Cd}$, copper $(\mathrm{Cu})$, iron (Fe), zinc $(\mathrm{Zn})$, manganese $(\mathrm{Mn})$ and reduced glutathione concentration were investigated in Tagetes patula L. plant growing in hydroponic culture media. Plants were grown under controlled conditions in Hoagland nutrient solution as 3 replications for 15 days. At the end of the experiments, despite the reduction in shoot and root dry weights with the increasing $\mathrm{Cd}$ treatments, $\mathrm{Cd}$ concentrations and contents increased. Tagetes plants have accumulated eight fold $\mathrm{Cd}$ than hyperaccumulation value $\left(100 \mathrm{mg} \mathrm{Cd} \mathrm{kg}^{-1}\right)$ in shoots. This result indicated that Tagetes patula $\mathrm{L}$. plant had great potential for phytoremediation to clean up Cd-contaminated soils.
\end{abstract}

Key Words: Heavy metal, phytoremediation, reduced glutathion, cadmium, Tagetes patula L. 


\section{Giriș}

Ağır metaller hava, toprak ve su kirliliğine neden olan bașlıca kirleticiler arasında yer alırlar. Amerikan Toksik Maddeler ve Hastalık Kayıt Ajansı'nın 2015 yılı verilerine göre kadmiyum (Cd) insan sağlığı açısından en toksik maddeler içinde 7 . sırada yer almaktadır (ATSDR, 2015). Kadmiyum, doğal olarak ya da insan faaliyetleri sonucunda toprakta bulunur. Tarımda kullanılan fosforlu gübreler, madencilik faaliyetleri, maden cevherlerinin rafine edilmesi, arıtma çamurları ve endüstriyel faaliyetler sonucu topraklar Cd ile kirlenmektedir (Namdjoyan vd., 2012; Sangwan vd., 2013; Thamayanthi vd., 2013; Dağhan vd., 2014). Bilinçsiz gübreleme, doğal veya antropojenik etkenlerle toprak pH'sının düșmesi Cd'un çözünürlüğünü arttırarak tarım ürünlerine geçișini kolaylaștırır. Ham fosfat kayası her zaman belirli bir düzeyde Cd içerir (Köleli ve Kantar, 2005). Fosfatlı gübrelerin üretilmesi ișçi sağlığını olumsuz yönde etkilerken, gübre olarak kullanılması toprağın Cd ile kirlenmesine neden olur (Köleli ve Kantar, 2005; Ertem, 2011).

Diğer yandan bitki tarafından alınan Cd bitkide birçok fizyolojik, biyokimyasal ve strüktürel değișime neden olabilir (Thamayanthi vd., 2013; Mansour vd., 2015). Kadmiyum akümülasyonu mineral besin elementleri alımını değiștirir, bitkinin su dengesi ile etkileșime girerek stomaların açılmasını engeller, Calvin döngüsü enzimlerini, fotosentezi ve karbonhidrat metabolizmasını bozar, antioksidan metabolizmasını değiștirir ve ürün verimini düșürür (Nazar vd., 2012). Ayrıca Cd toksisitesinin bitki besin elementlerinin alınabilirliği, yarayıșlılı̆̆ ile etkileșimi olduğu ve hatta bazı besin elementlerinin Cd'un toksik stresine karșı bitkiyi koruyucu bir role sahip olduğunu göstermiștir (Nazar vd., 2012; Thamayanthi vd., 2013).

Topraklardan bitkilere oradan da besin zinciri yoluyla insan ve hayvanlara geçen Cd canlılar için oldukça tehlikeli ve toksik etkili bir elementtir. İtai itai hastalığı Cd zehirlenmesine bağı olduğu saptanan ilk hastalıktır. Bu hastalık, Japonya'nın Toyama bölgesinde ilk kez 1950 yılında Zn madeni atıkları ile kirlenmiș nehir sularıyla sulanan çeltik tarlalarında yetișen Cd içeriği yüksek pirinçle beslenen insanlarda görülmüștür (Ertem, 2011). Canlı sağlığını ciddi anlamda tehdit eden Cd ile kirlenmiș tarım topraklarının arııımında fiziksel, kimyasal ve biyolojik yöntemler kullanılabilir. Ancak bu yöntemlerden özellikle fiziksel ve kimyasal yöntemler uygulanmalarındaki zorluklar, pahalı ve uzun süren yöntemler olmaları nedeniyle tercih edilmemektedir.
Biyolojik yöntemlerden biri olan fitoremediasyon toprak kirliliğine neden olan metalin, bitki kökleri yolu ile alınarak bitkinin yeșil aksamına tașınması ve biriktirilmesidir. Bu yöntem diğer yöntemlere göre ucuz, etkili, çevre dostu ve kolay uygulanabilir bir yöntemdir (Lal vd., 2008; Lin vd., 2010; Sheoran vd., 1990; Dağhan vd., 2012; Thamayanthi vd., 2013; Eren ve Dağhan, 2014). Fitoremediasyon yönteminde kullanılacak bitkinin; hasat edilebilir aksamında yüksek oranda metal biriktirmesi, biriken ağır metale tolerans göstermesi, hızlı büyüyebilen, derin köklü ve kolayca hasat edilebilir olması gerekmektedir (Dağhan, 2004; Dağhan, 2007; Dağhan vd., 2012). Doğada hiperakümülatör adı verilen yeșil aksamında normal bitkiden daha fazla metal akümüle eden bitkiler bulunmaktadır. Bu bitkilerin ağır metale göre akümülasyon kapasiteleri farklıdır. Genel olarak bu bitkiler yeșil aksamlarında kuru kütle esasına göre $10000 \mathrm{mg} \mathrm{kg}^{-1} \mathrm{Zn}$ ve Mn, $1000 \mathrm{mg} \mathrm{kg}^{-1} \mathrm{Co}, \mathrm{Cu}, \mathrm{Ni}$, As ve Se, $100 \mathrm{mg} \mathrm{kg}^{-1} \mathrm{Cd}$ biriktirebilmektedirler (Rungruang vd., 2011 ). Diğer metallerin akümülasyon miktarı ile kıyaslandığında Cd'un $100 \mathrm{mg} \mathrm{kg}^{-1}$ derișiminde biriktirmeleri bu elementin toksik etkisinin ne kadar fazla olduğunu göstermektedir. Bu nedenle $\mathrm{Cd}$ ile kirlenmiș toprakların temizlenmesinde iklim, toprak seçiciliği olmayan, hızlı büyüyen, bol yeșil aksama sahip ve yüksek miktarda Cd' u yeșil aksamında biriktirebilen ve besin zincirine dâhil olmayacak (besin olarak tüketilmeyen) hiperakümülatör bitkilerin araștırılması gerekmektedir.

Tagetes patula (Kadife çiçeği) bitkisi estetik olarak güzel bir görünüme sahip, toprak ve iklim seçiciliği az olan, farklı iklim ve toprak koșullarına adapte olmuș (Liu vd., 2011 ) ve çok kolay yetiștirilebilen tek yıllık çiçek türlerinden biridir (Liu vd., 2011; Priyanka vd., 2013). Bu özelliklerinin yanı sıra Liu vd., 2011 ve Priyanka vd., (2013)'nın bildirdiğine göre bu bitki tarımsal üretim için de faydalı bir bitki olarak kullanılmaktadır. Köklerinden salgıladıkları alfatertienil kök uru ve lezyon nematodlarının kontrolünde oldukça etkili bir nematisittir. Allelopatik etki nedeniyle Tagetes patula, ürünleri nematodlara karșı koruyabilmek için tamamlayıcı ya da refakatçi bitki olarak bitkisel üretim sisteminde kullanılır (Liu vd., 2011; Priyanka vd., 2013). Besin olarak tüketilen bitkiler, akümüle ettikleri ağır metalin besin zincirine katılma olasılı̆̆ından dolayı ağır metallerle kirlenmiș toprakların fitoremediasyonu için uygun değildirler (Lin vd., 2010). Dolayısıyla Tagetes patula bitkisi tek yıllık bir süs bitkisi olması, yenilen bir 
bitki olmaması ile Cd'un olası toksik etkisi minimize edildiği için kirlenmiș topraklarda yetiștirilmesi uygun bir bitkidir (Lal vd., 2008; Lin vd., 2010; Liu vd., $2011)$

Bu çalıșma ile Tagetes patula L. bitkisinin su kültürü koșulunda artan dozlarda Cd uygulamalarına tolerans ve birikim düzeyi ile fitoremediasyon potansiyeli araștııılmıștır.

\section{MATERYAL VE YÖNTEM}

Denemede Tagetes patula L. (Kadife çiçeği) tohumları bitki materyali olarak kullanılmıștır. Tagetes patula L. bitkisinin tohumları, torf:perlit karıșımı (1:1) ortamında kontrollü koșullarda çimlendirilmiș ve bitkiler 2-3 yapraklı hale gelip hafif köklendikten sonra besin çözeltisine aktarılmıștır. Besin çözeltisinin kompozisyonu; 1 $\mathrm{mM} \mathrm{KH}_{2} \mathrm{PO}_{4}, 3 \mathrm{mM} \mathrm{KNO}_{3}, 0.25 \mathrm{mM} \mathrm{MgSO}_{4} .7 \mathrm{H}_{2} \mathrm{O}$, $2 \mathrm{mM} \mathrm{Ca}\left(\mathrm{NO}_{3}\right) 2.4 \mathrm{H}_{2} \mathrm{O}, 0,1 \mathrm{mM}$ FeEDTA, $1 \times 10^{-3}$ $\mathrm{mM} \mathrm{MnSO}_{4} \cdot \mathrm{H}_{2} \mathrm{O}, 1 \times 10^{-3} \mathrm{mM} \mathrm{ZnSO}_{4} \cdot \mathrm{H}_{2} \mathrm{O}, 0.25 \times 10^{-3}$ $\mathrm{mM} \mathrm{CuSO}_{4} \cdot \mathrm{H}_{2} \mathrm{O}, 0.25 \times 10^{-3} \mathrm{mM}\left(\mathrm{NH}_{4}\right) 6 \mathrm{Mo}^{2} \mathrm{O}_{24}$, $2.5 \times 10^{-2} \mathrm{mM} \mathrm{KCl} 1.25 \times 10^{-2} \mathrm{mM} \mathrm{H}_{3} \mathrm{BO}_{3}$ ve $\mathrm{pH}$ 5,2'dir.

Her uygulama 3 paralel olarak yapılmıș ve $\mathrm{Cd}$ besin çözeltisine $3 \mathrm{CdSO}_{4} .8 \mathrm{H}_{2} \mathrm{O}$ formunda $0,5,10$, 20 ve $40 \mu \mathrm{M}$ dozlarında uygulanmıștır. Besin çözeltisi her 2-3 günde bir değiștirilmiștir. Bitkiler besin çözeltisi ortamında ve kontrollü koșullarda (16/8 saat ıșı/karanlıkta, $25 / 20{ }^{\circ} \mathrm{C}$ sıcaklık ve \% 6070 nem, ıșık yoğunluğu 10 klux) 15 gün süre yetiștirilmiștir. Denemeler süresince ağır metal toksisitesi karșısında bitkilerin uğradıkları morfolojik değișimler gözlenmiștir.

\section{Bitki Örneklerinin Hasadı ve Analizleri}

Su kültüründe 15 gün süre ile yetiștirilen bitki örnekleri yeșil aksam ve kök olarak hasat edilmiștir. Kök ve yeșil aksam örnekleri saf suyla yıkandıktan sonra kurutma dolabında $65^{\circ} \mathrm{C}$ 'de sabit ağırlığa gelinceye kadar kurutulmuș ve bitkilerin kuru ağırlıkları alınarak agat tașlı bitki öğütme değirmeninde öğütülmüștür. Öğütülen bitki örnekleri $\mathrm{HNO}_{3}$ ile mikro dalga firında çözünürleștirilerek toplam element konsantrasyonu (Cd, Cu, Fe, Mn, Zn,) ICP-AES (Inductively Coupled Plasma-Atomic Emmission Spectrometry; Varian Series-II)'de belirlenmiștir. Üç paralelli yapılan metal analizlerinin doğruluğu, metal içeriği belli standart sertifikalı bir bitki (Virginia Tobacco Leaves (CTA-VTL2)) örneğinin aynı yöntemle analiz edilmesi ile kontrol edilmiștir.

\section{Bitki Örneklerinde İndirgenmiș Glutatyon (-SH) Analizi}

Total SH-grupları Çakmak ve Marschner (1992)'ye göre yapılımıștır. Yaklașık olarak 0,5 g yaș bitki örneği (yaprak ve kök) 5 mL \% 5 metaffosforik asitle ekstrakte edilerek, 400 rpm'de 30 dakika santrifüj edilmiștir. Santrifüj tüpünün üstünde kalan çözeltiden $0,5 \mathrm{~mL}$ çözelti alınarak üzerine fosfat tamponu $(\mathrm{pH} 7,4)$ içinde hazırlanmıș 0,5 mL DTNB (5,5'-dithiobis 2nitrobenzoik asit) ilave edilmiștir. Standart olarak 0-100 $\mathrm{gg} \mathrm{L}^{-1}$ aralığında redükte glutatyon \% 5'lik metafosforik asit (m/v) içinde hazırlanmıștır. Örnekler ve glutatyon ile hazırlanan standartların -SH konsantrasyonları 20 dakika sonra $412 \mathrm{~nm}$ dalga boyunda spektrofotometrede belirlenmiștir.

\section{İstatistiksel Analizler}

Su kültürü sonucunda elde edilen veriler MSTAT-C programı kullanılarak değerlendirilmiș ve ortalamalar arasındaki fark LSD testi uygulanarak gruplandırılmıștır.

\section{BULGULAR VE TARTIȘMA}

Deneme boyunca Cd'un bitkiler üzerindeki etkileri gözlenmiștir. Kontrol bitkilerinin kök ve yeșil aksamı sağılılı, bol biyomaslı olarak gelișim göstermiștir. Kadmiyum uygulamasındaki artıșla birlikte yeșil aksam ve kök büyümesi azalmıș, alt yapraklarda bașlayan hafif sararma doz artıșı ile artmıștır ve hafif kurumalar gözlenmiștir. Denemenin bașlangıcında $5 \mu \mathrm{M}$ Cd uygulanmıș bitkilerin yapraklarında çok hafif kloroz, ancak $10-20$ ve $40 \mu \mathrm{M}$ Cd uygulanmıș

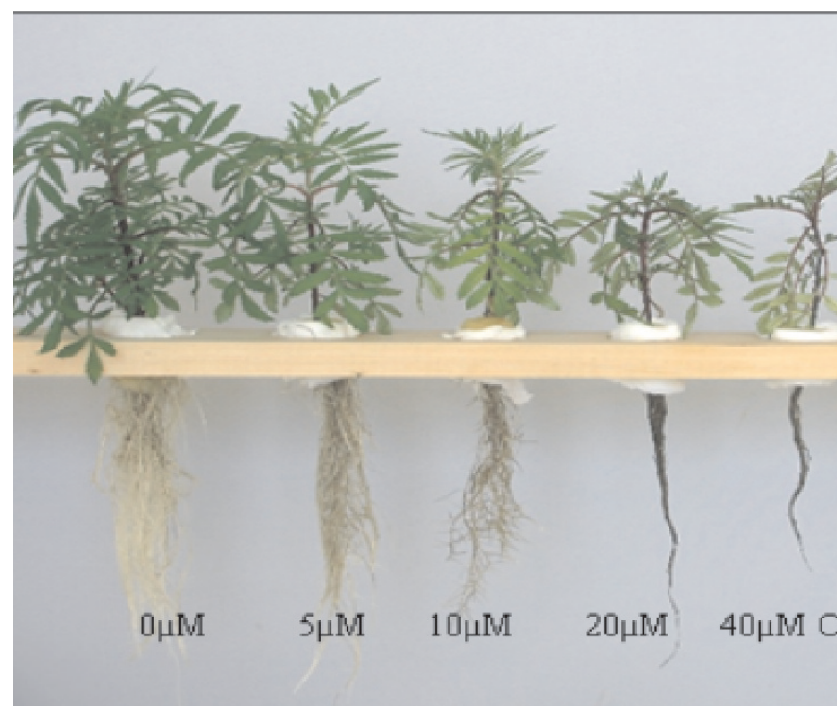

Șekil 1. Artan dozlarda Cd uygulamasının Tagetes patula L. bitkisinin büyümesi üzerine etkileri

Figure 1. The effects of increasing Cd treatments on growth of Tagetes patula L. plant 
bitkilerde orta ve șiddetli kloroz ve nekrozlar gözlenmiștir. Kontrol bitkisinin kökleri beyaz ve iyi gelișmișken $5 \mu \mathrm{M}$ Cd uygulamasında bașlayan hafif kahverengileșme $40 \mu \mathrm{M}$ dozunda koyu kahverengine dönüșmüș ve büyüme șiddetli bir șekilde azalmıștır (Șekil 1).

Kadmiyum bitki bünyesinde azot ve karbonhidrat metabolizmalarını değiștirmesi nedeniyle birçok fizyolojik değișikliğe neden olmaktadır. Fotosentezi engellemekte, stomaların kapanmasına ve klorofil biyosentezinin bozulmasına, serbest radikallerin olușmasına neden olmaktadır (Sheoran vd., 1990; Zengin ve Munzuroğlu, 2005; Mansour vd., 2015). Așırı Cd dozlarının klorofil biyosentezini bozmasının en önemli nedeni klorofil biyosentezinde görev yapan protoklorofil reduktaz ile aminolevulinik asit sentezini engellemesidir (Zengin ve Munzuroğlu, 2005).

Artan dozlarda Cd uygulamalarının Tagetes patula L. bitkisinin yeșil aksam ve kök kuru kütleleri üzerine etkileri Sekil 2 ve Tablo 1-2'de verilmiștir. Kadmiyum dozlarındaki artıșla birlikte yeșil aksam ve kök kuru ağırlıklarında azalma istatistiksel olarak önemli bulunmuștur $(p<0,01)$.

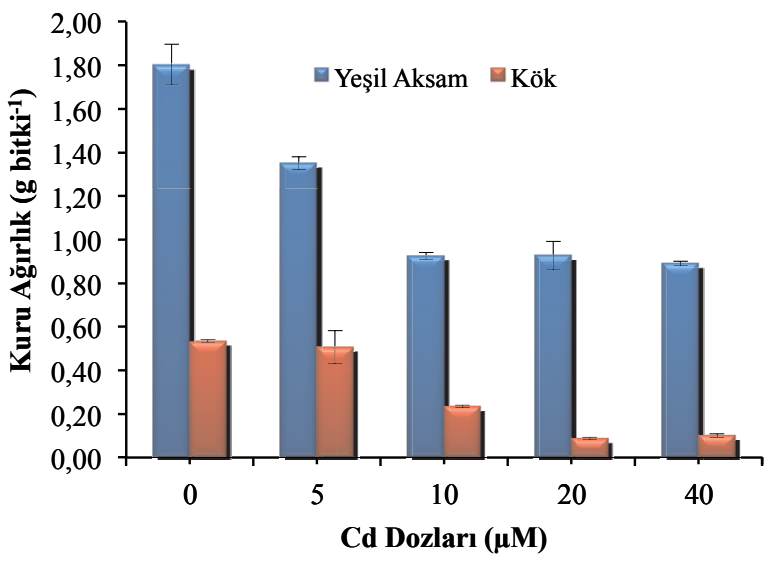

Sekil 2. Artan dozlarda Cd uygulamalarının Tagetes patula L. bitkisinin kuru kütlesi üzerine etkileri

Figure 2. The effects of increasing Cd treatments on dry weights of Tagetes patula L. plant
En yüksek yeșil aksam kuru kütle 1,803 $\mathrm{g}$ bitki-1 ile

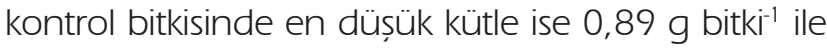
$40 \mu \mathrm{M}$ Cd uygulamasında tespit edilmiștir (Çizelge 1).

Köklerde ise, en fazla kuru ağırlık 0,533 $\mathrm{g} \mathrm{bitki}^{-1}$ ile kontrol bitkisinde ve en az kuru ağırlık 0,100 g bitki $^{-1}$ ile $40 \mu \mathrm{M}$ Cd uygulamasında elde edilmiștir (Çizelge 2). Benzer sonuçlar Liu vd., (2011) tarafından da elde edilmiștir.

Organik kirleticilerin aksine Cd gibi inorganik kirleticiler doğada bozulmaya uğramazlar ve kalıcıdırlar. Bu nedenle de ağır metal akümüle edebilen bitkiler tarafindan alınarak topraktan tașınabilirler. Yüksek bitkiler Cd stresine karșı oldukc̦a hassastırlar. Yapılan araștırmalar toprakta bulunan yüksek konsantrasyonlardaki Cd'un bitkilerin büyüme, gelișme ve metabolizmasını olumsuz etkilediğini, tohumun çimlenmesini engellediğini göstermiștir (Benavides vd., 2005, Hall, 2002; Mishra vd., 2006; Mohan ve Hosetti, 1997). Kadmiyum stresi sonucunda bitki biyomasında azalmalar farklı süs bitkileri ile (Krizantem, Gladiolus ve Tagetes (Lal vd., 2008; Tagetes patula L. (Liu vd., 2011 ); Tagetes erecta L. (Thamayanth vd., 2013; Mansour vd., 2015) yapılan birçok araștırmada da görülmüștür.

Kadmiyum uygulamalarındaki artıșla kuru ağılıklardaki azalmanın aksine bitkilerin kök ve yeșil aksam Cd konsantrasyonlarında istatistiksel olarak önemli bir artıș görülmüștür $(p<0,01)$. En yüksek $C d$ konsantrasyonu yeșil aksamda $3633 \mathrm{mg} \mathrm{kg}^{-1}$ ve kökte ise $22942 \mathrm{mg} \mathrm{kg}^{-1}$ ile 40 HM Cd uygulama dozunda elde edilmiștir (Șekil 3, Çizelge 1, 2).

Liu vd., (2011) benzer bir çalıșmada 14 gün süre ile 10-25-50 $\mu \mathrm{M}$ CdCl2 uyguladıkları Tagetes patula bitkisinden en fazla Cd konsantrasyonunu yeșil aksamda $450 \mathrm{mg} \mathrm{kg}^{-1}$ ve kökte ise $3500 \mathrm{mg} \mathrm{kg}^{-1}$ elde etmișlerdir. Bu çalıșmada ise, $\mathrm{CdSO}_{4}$ formunda en yüksek Cd (40 M) dozunda Liu vd., (2011)'nın

Çizelge 1. Artan dozlarda Cd uygulamalarının Tagetes patula L. bitkisinin yeșil aksam (YA) kuru kütle, Cd, Cu, Fe, Mn ve Zn konsantrasyonları, Cd içeriği ve -SH konsantrasyonları üzerine etkileri

Table 1. The effects of increasing Cd treatments on dry weights, Cd, Cu, Fe, Mn and Zn concentrations, Cd content and -SH concentrations of Tagetes patula L. plant shoots

\begin{tabular}{|c|c|c|c|c|c|c|c|c|}
\hline $\begin{array}{l}\mathrm{Cd} \\
\mu \mathrm{M}\end{array}$ & $\begin{array}{l}\text { Kuru Kütle } \\
\text { g bitki }{ }^{-1}\end{array}$ & $\begin{array}{c}\mathrm{Cd} \\
\mathrm{mg} \mathrm{kg}^{-1}\end{array}$ & $\begin{array}{c}\mathrm{Cu} \\
\mathrm{mg} \mathrm{kg}^{-1}\end{array}$ & $\begin{array}{c}\text { Cd } \\
\mu \mathrm{g} \text { bitki }^{-1}\end{array}$ & $\begin{array}{c}\mathrm{Fe} \\
\mathrm{mg} \mathrm{kg}^{-1}\end{array}$ & $\begin{array}{c}\mathrm{Mn} \\
\mathrm{mg} \mathrm{kg}^{-1}\end{array}$ & $\begin{array}{c}\mathrm{Zn} \\
\mathrm{mg} \mathrm{kg}^{-1}\end{array}$ & $\begin{array}{c}-\mathrm{SH} \\
\mu \mathrm{g} \mathrm{mL}^{-1 *}\end{array}$ \\
\hline 0 & $1,803 a$ & $0,67 e$ & $48,54 a$ & $1,199 \mathrm{e}$ & $492 a$ & $274 a$ & 72,23 a & $1419 \mathrm{e}$ \\
\hline 5 & $1,350 \mathrm{~b}$ & $854 d$ & $17,96 b$ & $1153 d$ & $112 c$ & $123 c$ & $64,35 \mathrm{~b}$ & $11258 \mathrm{c}$ \\
\hline 10 & $0,925 c$ & $1522 c$ & $14,28 d$ & $1408 \mathrm{C}$ & $160 \mathrm{~b}$ & $167 \mathrm{~b}$ & $65,96 \mathrm{~b}$ & $13179 \mathrm{~b}$ \\
\hline 20 & $0,927 c$ & 1676b & $15,93 c$ & $1553 \mathrm{~b}$ & $128 \mathrm{c}$ & $171 \mathrm{~b}$ & $53,26 \mathrm{C}$ & $10248 d$ \\
\hline 40 & $0,890 \mathrm{c}$ & 3633a & $14,56 \mathrm{~cd}$ & 3233 а & $75,58 d$ & $116 \mathrm{C}$ & $44,38 d$ & 18413 a \\
\hline LSD \%5 & $0,111 * *$ & $18,89 * *$ & $1,53^{* *}$ & $88,68 * *$ & $30,03^{* *}$ & $34,77^{* *}$ & $3,76 * *$ & $909,92^{* *}$ \\
\hline
\end{tabular}


Çizelge 2. Artan dozlarda Cd uygulamalarının Tagetes patula L. bitkisinin kök kuru ağırlığı, Cd, Cu, Fe, Mn ve Zn konsantrasyonları, Cd içeriği ve -SH konsantrasyonları üzerine etkileri

Table 2. The effects of increasing Cd treatments on dry weights, Cd, Cu, Fe, Mn and Zn concentrations, Cd content and$S H$ concentrations of Tagetes patula $L$. plant roots

\begin{tabular}{|c|c|c|c|c|c|c|c|c|}
\hline $\begin{array}{r}C d \\
\mu M\end{array}$ & $\begin{array}{c}\text { Kuru Kütle } \\
\mathrm{g} \mathrm{bitki}^{-1}\end{array}$ & $\begin{array}{c}\mathrm{Cd} \\
\mathrm{mg} \mathrm{kg}^{-1}\end{array}$ & $\begin{array}{c}\mathrm{Cu} \\
\mathrm{mg} \mathrm{kg}^{-1}\end{array}$ & $\begin{array}{c}\text { Cd } \\
\mu \mathrm{g} \text { bitki }^{-1}\end{array}$ & $\begin{array}{c}\mathrm{Fe} \\
\mathrm{mg} \mathrm{kg}^{-1}\end{array}$ & $\begin{array}{c}\mathrm{Mn} \\
\mathrm{mg} \mathrm{kg}^{-1}\end{array}$ & $\begin{array}{c}\mathrm{Zn} \\
\mathrm{mg} \mathrm{kg}^{-1}\end{array}$ & $\begin{array}{c}-\mathrm{SH} \\
\mu \mathrm{gL}^{-1 *}\end{array}$ \\
\hline 0 & 0,533 a & $8,57 \mathrm{e}$ & $155 \mathrm{~b}$ & $4,57 d$ & $3229 \mathrm{e}$ & 198 a & 114 & $1475 \mathrm{~d}$ \\
\hline 5 & 0,507 a & $1436 d$ & $119 \mathrm{c}$ & $725 \mathrm{c}$ & $4576 \mathrm{~d}$ & $24,91 \mathrm{~b}$ & 55,9 & $2747 \mathrm{c}$ \\
\hline 10 & $0,233 \mathrm{~b}$ & $3472 \mathrm{c}$ & $167 \mathrm{~b}$ & $810 c$ & $6523 \mathrm{c}$ & $26,81 \mathrm{~b}$ & 143,95 & $1208 d$ \\
\hline 20 & $0,087 \mathrm{c}$ & $14942 \mathrm{~b}$ & 248 a & $1295 \mathrm{~b}$ & 12784 b & $25,00 \mathrm{~b}$ & 169,3 & $6604 \mathrm{D}$ \\
\hline 40 & $0,100 \mathrm{c}$ & 22942 a & 243 a & 2294 a & 13605 a & $21,42 \mathrm{~b}$ & 129,63 & 23089 a \\
\hline LSD \%5 & $0,072 * *$ & $369,749 * *$ & $18,98 * *$ & $244,76 * *$ & $802,45 * *$ & $8,57 * *$ & öd & $986,18 * *$ \\
\hline
\end{tabular}

*YA: Yaș Ağırlık ** $p<0,01 \quad$ öd: önemli değil

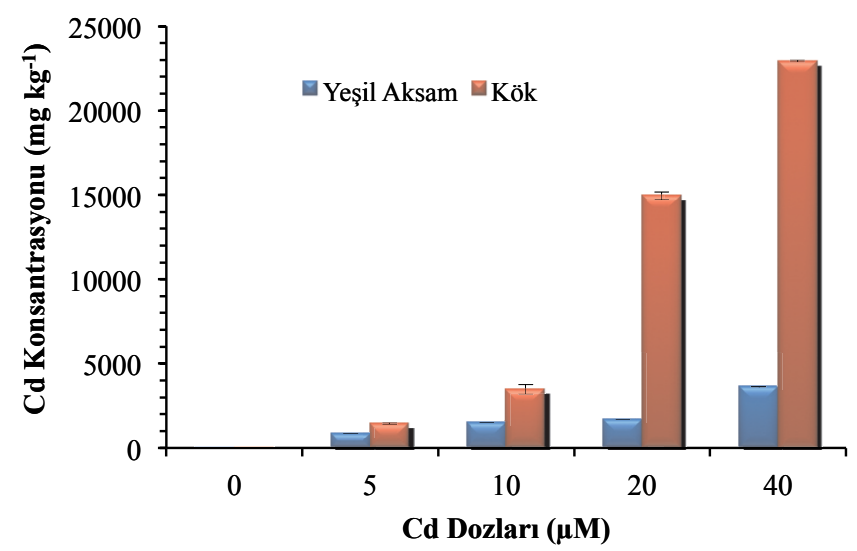

Șekil 3. Artan dozlarda Cd uygulamalarının Tagetes patula L. bitkisinin kuru kütlesi üzerine etkileri

Figure 3. The effects of increasing Cd treatments on dry weights of Tagetes patula L. plant

çalıșmasından daha fazla Cd akümülasyonu elde edilmiștir. Bitkilerin $\mathrm{Cd}$ akümülasyonunun ve içeriğinin, Cd dozlarındaki artıșla arttığı sonucunu Lin vd., 2010, Rungruang vd., (2011) tarafindan yapılan çalıșmalarda da elde edilmiștir.

Kabata-Pendias (2011), bitki dokularındaki normal Cd değerinin 0,05-0,2 $\mathrm{mg} \mathrm{kg}^{-1}$ ve toksik Cd değerinin ise $5-30 \mathrm{mg} \mathrm{kg}^{-1}$ olduğunu bildirmiștir. Kadmiyum hiperakümülatörü bitkiler ise bünyelerinde $100 \mathrm{mg} \mathrm{kg}^{-1} \mathrm{Cd}$ biriktirebilmektedirler (Rungruang vd., 2011). Tagetes patula L. bitkisi en düșük Cd dozu (5 $\mu \mathrm{M}$ ) uygulamasında bile kökte $1436 \mathrm{mg} \mathrm{kg}^{-1}$ (14 kat) ve yeșil aksamında $854 \mathrm{mg}$ $\mathrm{kg}^{-1} \quad$ (8 kat) Cd biriktirerek toksik değer ve hiperakümülator bitkilerin $\mathrm{Cd}$ akümülasyon değerinden fazla $\mathrm{Cd}$ biriktirmiștir. Fitoremediasyon yönteminde kullanılacak bitkinin özellikle yeșil aksamında yüksek oranda ağır metal biriktirmesi gerekmektedir. Bu durumda Tagetes bitkisi hiperakümülator bitkilerin C $\mathrm{d}$ birikim düzeyinin 8 ile
36 katı fazla oranında dokularında $\mathrm{Cd}$ biriktirdiğinden $\mathrm{Cd}$ ile kirlenmiș toprakların temizlenmesinde önerilebilecektir. Benzer șekilde Liu vd., (2011) Tagetes patula bitkisinin yeșil aksamında $4501 \mathrm{mg} \mathrm{kg}^{-1}$ Cd biriktirdiğini ve bu değerin standart Cd akümülasyon değerinden (100 mg $\left(d ~ k g^{-1}\right.$ ) daha yüksek olduğunu bildirmișlerdir.

Bu çalıșmada bitkilerin konsantrasyonlarının kuru ağırlıkla çarpımları sonucu bitki bașına biriktirdikleri Cd içerikleri de hesaplanmıștır. Sonuçlar kuru ağırlıklardaki azalmaya rağmen bitkilerin yeșil aksam ve kök Cd içeriklerinde önemli bir artıș olduğunu göstermiștir (Çizelge 1, 2). Yeșil aksamda en yüksek Cd içeriği $3233 \mu \mathrm{g}$ bitki $^{-1}$ ve kökte ise $2294 \mu \mathrm{g}$ bitki $^{-1}$ ile $40 \mu \mathrm{M}$ Cd dozunda sağlanmıștır.

Artan dozlarda Cd uygulamalarının yeșil aksam ve kökün $\mathrm{Cu}, \mathrm{Fe}, \mathrm{Mn}$ ve $\mathrm{Zn}$ konsantrasyonları üzerine etkileri köklerin Zn konsantrasyonu dıșında istatistiksel olarak önemli bulunmuștur $(p<0,01)$ (Çizelge 1). Kadmiyum uygulamalarında yeșil aksamın Cu, Fe, Mn ve Zn konsantrasyonları kontrol bitkisine göre azalma göstermiștir. Köklerde ise en yüksek Cu (243 mg kg-1) ve Fe (13605 mg kg-1) 40 HM Cd uygulamasında ve en yüksek Mn konsantrasyonu ise (198 $\mathrm{mg} \mathrm{kg}^{-1}$ ) kontrol bitkisinde tespit edilmiștir (Çizelge 2). Thamayanthi vd., (2013)'nin yaptıkları çalıșma, sonuçlarımızı desteklemektedir. Araștırmacılar artan dozlarda (020-40-60-80 ve $100 \mathrm{mg} \mathrm{kg}^{-1}$ ) Cd uyguladıkları saksılarda Marigold (Tagetes erecta L.) bitkisinin Cd alımı ve Cd'un bitkinin besin elementi (N, P, K, Fe, $\mathrm{Mn}, \mathrm{Cu}, \mathrm{Zn})$ içeriğine etkilerini araștırmıșlardır. Toplam 60 günlük saksı denemesi sonunda $\mathrm{Cd}$ dozundaki artıșla bitkilerin büyümelerinde ve besin elementi içeriklerinde azalmalar olduğunu tespit etmișlerdir. Çalıșmada Cd uygulaması ile Tagetes erecta L. bitkisinin $\mathrm{Cu}$ içeriğinin azaldığını bildirmișlerdir. 
Yeșil aksam -SH konsantrasyonu Cd uygulanmıș dozlarda (5-1 0-20 ve $40 \mu \mathrm{M})$ kontrole $(0 \mu \mathrm{M})$ oranla önemli bir düzeyde yüksek bulunmuștur. Bu sonuç Cd'un diğer elementlerle olan rekabetinden kaynaklı olabilir. Ağır metaller, kuraklık, tuzluluk, hava kirliliği gibi stres koșullarında bitkilerde hücrelere zarar veren serbest oksijen radikalleri sentezlenmektedir. Bitkiler sentezlenen bu radikallerin zararını önlemek ve onları zararsız bileșiklere dönüștürmek için antioksidatif savunma mekanizmasına sahiptirler. Bu antioksidantların bașında süper oksit dismütaz (SOD), askorbat peroksidaz (APX), glutatyon redüktaz (GR) vb. gelmektedir (Cakmak ve Marschner, 1992). Ayrıca SH-bileșikleri (glutatyon), stres durumunda olușan serbest radikallerle reaksiyona girerek enzimlerin $\mathrm{SH}$ (sulfidril) gruplarının okside olmasını önler.

\section{SONUÇLAR}

Bu çalıșmada Tagetes patula bitkisinin yeșil aksamında Cd akümülasyon değeri olan 100 mg $\mathrm{Cd} \mathrm{kg}^{-1}$ konsantrasyonundan 36 kat fazla 13633 mg Cd kg-1) Cd biriktirebildiği tespit edilmiștir. Bu sonuç Tagetes patula bitkisinin Cd ile kirlenmiș toprakların fitoremediasyonunda kullanım potansiyelinin yüksek olduğunu göstermektedir. Diğer yandan Tagetes patula bitkisi tek yıllık bir süs bitkisi olması, yenilen bir bitki olmaması ile Cd'un gıda zincirine katılarak toksik etki göstermesi önlenmiș olur. Tagetes bitkisinin yeșil aksamında yüksek oranda Cd biriktirebilen akümülatör bir bitki olması, toprak ve iklim seçiciliğinin olmaması, köklerinden nemotodlara karșı bitkileri koruyan nematisit salgılamaları gibi özelliklerinden dolayı tarımsal üretim için de yetiștirilebilmektedir. Yukarda değinilen nedenlerden ve elde edilen sonuçlar Tagetes patula L bitkisinin hem kirlenmiș toprakların temizlenmesinde kullanım potansiyelinin olduğu hem de tarımsal üretimde refakatçi bitki olarak tercih edilebileceğini göstermektedir.

\section{KAYNAKLAR}

ATSDR (2015). Priority List of Hazardous Substances Agency for Toxic Substances and Diseases. Available: http://mww.atsdr.cdc.gov/spl/resources/atsdr_2015_spl_detai led_data_table.pdf

Benavides M P, Gallego S M, and Tomaro M L (2005). Cadmium toxicity in plants. Brazilian Journal of Plant Physiology, 17: 21-34.

Cakmak I, Marschner H (1992). Magnesium deficiency and high light intensity enhance activities of superoxide dismutase, ascorbate peroxidase and glutathione reductase in bean leaves. Plant Physiology, 98:1222-1227.
Dağhan H (2004). Phytoextraction of heavy metal from contaminated soils using genetically modified plants. RWTHAachen Fakultät für Mathematik, Informatik und Naturwissenschaften, Institut fur Umweltforschung (Biology V), Doktor Arbeit, Aachen-Germany.

Dağhan H (2007). Fitoremediasyon: bitki kullanılarak kirlenmiș alanların temizlenmesi. GAP V. Tarım Kongresi Bildiri Kitabı, 362-367, 17-19 Ekim, Șanlıurfa.

Dağhan H, Köleli N, Uygur V, Arslan M, Önder D, Göksun V, Ağca N (2012). Kadmiyum ile kirlenmiș toprakların fitoekstraksiyonla arıtımında transgenik tütün bitkisinin kullanımının araștırılması. Toprak Su Dergisi, 1:1-6.

Dağhan H, Arslan M, Uygur V, Köleli N, Eren A (2014). The cadmium phytoextraction efficiency of ScMTll gene bearing transgenic tobacco plant. Biotechnology and Biotechnological Equipment, 24(3):1974-1978.

Eren A, Dağhan H (2014). Transgenic tobacco-bearing PcV-ChMTIIGFP gene accumulated more lead compared to wild type. Polish Journal of Environmental Studies, 23(2):569-571.

Ertem M (201 1). Itai Itai hastalığı.Erișim:http://mww.cevres agligi.org/cevresagligi/kutuphane/ii.-ulusal-cevre-hekimligi kongresi/itai-itai-hastal.html

Hall J L (2002). Cellular mechanisms for heavy metal detoxification and tolerance. Journal of Experimental Botany, 53:1-11

Kabata-Pendias A, (2011). Trace elements in soils and plants, 4th ed. CRC Press, Boca Raton, London, FL.

Köleli N, Kantar Ç (2005). Fosfat kayası, fosforik asit ve fosforlu gübrelerdeki toksik ağır metal (Cd, Pb, Ni, As) konsantrasyonu. Ekoloji Dergisi, 14(55):1-5.

Lal K, Minhas P S, Chaturvedi S R K, Yadav R K (2008). Extraction of cadmium and tolerance of three annual cut flowers on Cd-contaminated soils. Bioresource Technology, 99:1006-1011.

Lin C C, Lai H Y, Chen Z S (2010). Bioavailability assessment and accumulation by five garden flower species grown in artificially cadmium-contaminated soils. International Journal of Phytoremediation, 12:1-14.

Liu Y T, Chen Z-S, Hong C Y (2011). Cadmium-induced physiological response and antioxidant enzyme changes in the novel cadmium accumulator, Tagetes patula. Journal of Hazardous Materials, 189 724-731.

Mansour H A, El-Maadawy E I, Ahmed H A H, Othman E Z (2015). Effect of different chemical additives on growth and flowering of African Marigold (Tagetes erecta L.) grown under cadmium stress. Journal of Horticultural Science and Ornamental Plants 7(1): 29-38

Mishra S, Srivastava S, Tripathi R D, Govindarajan R, Kuriakose S V, Prasad M N V (2006). Phytochelatin synthesis and responses of antioxidants during cadmium stress in Bacopa monneri L., Plant Physiology and Biochemistry, 44:2537.

Namdjoyan S, Namdjoyan S, Kermanian H (2012). Induction of phytochelatin and responses of antioxidants under cadmium stress in safflower (Carthamus tinctorius) seedlings. Turkish Journal of Botany, 36:495-502. 
Nazar R, labal N, Masood A, Khan M I R, Syeed S, Khan N A (2012). Cadmium toxicity in plants and role of mineral nutrients in its alleviation. American Journal of Plant Sciences, 3, 1476-1489. Available: http://dx.doi.org/10.4236/ajps. 2012.310178

Priyanka D, Shalini T, Navneet V K (2013). A brief study on Marigold (Tagetes Species): a review. International Research Journal of Pharmacy, 4(1):43-48.

Rungruang N, Babel S, Parkpian P (2011). Screening of potential hyperaccumulator for cadmium from contaminated soil. Desalination and Water Treatment, 32(1-3):19-26.

Sangwan P, Mor V, Sakshi, Soni R, Dhankhar R (2013). Toxicity of cadmium in plants. International Journal of Current Research, 5(9):2714-2717.
Sheoran I S, Singal H R, Singh R (1990). Effect of cadmium and nickel on photosynthesis and enzymes of the photosynthetic carbon reduction cycle in Pigeon Pea (Cajanus cajan L.). Photosynthesis Research, 23:345-351.

Thamayanthi D, Sharavanan P S, Jayaprasad B (2013). Phytoremediating capability biochemical changes and nutrient status of marigold (Tagetes erecta L.), plant under cadmium stress. International Journal of Research in Plant Science, 3(4): 57-63.

Zengin K F, Munzuroğlu Ö (2005). Fasulye fidelerinin (Phaseolus vulgaris L. Strike) klorofil ve karotenoid miktarı üzerine bazı ağır metallerin $\left(\mathrm{Ni}^{+2}, \mathrm{CO}^{+2}, \mathrm{Cr}^{+3}, \mathrm{Zn}^{+2}\right)$ Etkileri. F.Ü. Fen ve Mühendislik Bilimleri Dergisi, 17(1):164-172. 